\title{
SLC1 family of amino acid transporters (version 2019.4) in the IUPHAR/BPS Guide to Pharmacology Database
}

Philip M. Beart ${ }^{1}$

1. Florey Institute of Neuroscience and Mental Health, Australia

\begin{abstract}
The SLC1 family of sodium dependent transporters includes the plasma membrane located glutamate transporters and the neutral amino acid transporters ASCT1 and ASCT2 [1, 49, 36, 37, 7].
\end{abstract}

\section{Contents}

This is a citation summary for SLC1 family of amino acid transporters in the Guide to Pharmacology database (GtoPdb). It exists purely as an adjunct to the database to facilitate the recognition of citations to and from the database by citation analyzers. Readers will almost certainly want to visit the relevant sections of the database which are given here under database links.

GtoPdb is an expert-driven guide to pharmacological targets and the substances that act on them. GtoPdb is a reference work which is most usefully represented as an on-line database. As in any publication this work should be appropriately cited, and the papers it cites should also be recognized. This document provides a citation for the relevant parts of the database, and also provides a reference list for the research cited by those parts.

Please note that the database version for the citations given in GtoPdb are to the most recent preceding version in which the family or its subfamilies and targets were substantially changed. The links below are to the current version. If you need to consult the cited version, rather than the most recent version, please contact the GtoPdb curators.

\section{Database links}

SLC1 family of amino acid transporters

http://www.guidetopharmacology.org/GRAC/FamilyDisplayForward?familyld=139

Glutamate transporter subfamily

http://www.guidetopharmacology.org/GRAC/FamilyDisplayForward?familyld=163

Transporters

EAAT1(Excitatory amino acid transporter 1)

http://www.guidetopharmacology.org/GRAC/ObjectDisplayForward?objectld=868

EAAT2(Excitatory amino acid transporter 2)

http://www.guidetopharmacology.org/GRAC/ObjectDisplayForward?objectld=869

EAAT3(Excitatory amino acid transporter 3)

http://www.guidetopharmacology.org/GRAC/ObjectDisplayForward?objectld=870 
EAAT4(Excitatory amino acid transporter 4)

http://www.guidetopharmacology.org/GRAC/ObjectDisplayForward?objectld=871

EAAT5(Excitatory amino acid transporter 5)

http://www.guidetopharmacology.org/GRAC/ObjectDisplayForward?objectld=872

Alanine/serine/cysteine transporter subfamily

http://www.guidetopharmacology.org/GRAC/FamilyDisplayForward?familyld=164

Transporters

ASCT1(Alanine/serine/cysteine transporter 1)

http://www.guidetopharmacology.org/GRAC/ObjectDisplayForward?objectld=873

ASCT2(Alanine/serine/cysteine transporter 2)

http://www.guidetopharmacology.org/GRAC/ObjectDisplayForward?objectld=874

\section{References}

1. Amara SG and Arriza JL. (1993) Neurotransmitter transporters: three distinct gene families.Curr. Opin. Neurobiol. 3: 337-44 [PMID:8103691]

2. Apricò $K$, Beart PM, Crawford D and O'shea RD. (2007) Comparison of [(3)H]-(2S,4R)-4-methylglutamate and $[(3) \mathrm{H}] \mathrm{D}$-aspartate as ligands for binding and autoradiographic analyses of glutamate transporters. Neurochem. Int. 51: 507-16 [PMID:17590480]

3. Apricò K, Beart PM, Crawford D and O'Shea RD. (2004) Binding and transport of [3H](2S,4R)- 4methylglutamate, a new ligand for glutamate transporters, demonstrate labeling of EAAT1 in cultured murine astrocytes. J. Neurosci. Res. 75: 751-9 [PMID:14994336]

4. Apricó K, Beart PM, Lawrence AJ, Crawford D and O'Shea RD. (2001) [(3)H](2S,4R)-4-Methylglutamate: a novel ligand for the characterization of glutamate transporters. J. Neurochem. 77: 1218-25 [PMID:11389172]

5. Arriza JL, Kavanaugh MP, Fairman WA, Wu YN, Murdoch GH, North RA and Amara SG. (1993) Cloning and expression of a human neutral amino acid transporter with structural similarity to the glutamate transporter gene family. J. Biol. Chem. 268: 15329-32 [PMID:8101838]

6. Bailey CG, Ryan RM, Thoeng AD, Ng C, King K, Vanslambrouck JM, Auray-Blais C, Vandenberg RJ, Bröer S and Rasko JE. (2011) Loss-of-function mutations in the glutamate transporter SLC1A1 cause human dicarboxylic aminoaciduria. J. Clin. Invest. 121: 446-53 [PMID:21123949]

7. Beart PM and O'Shea RD. (2007) Transporters for L-glutamate: an update on their molecular pharmacology and pathological involvement. Br. J. Pharmacol. 150: 5-17 [PMID:17088867]

8. Boudker O, Ryan RM, Yernool D, Shimamoto K and Gouaux E. (2007) Coupling substrate and ion binding to extracellular gate of a sodium-dependent aspartate transporter. Nature 445: 387-93 [PMID:17230192]

9. Bröer A, Brookes N, Ganapathy V, Dimmer KS, Wagner CA, Lang F and Bröer S. (1999) The astroglial ASCT2 amino acid transporter as a mediator of glutamine efflux. J. Neurochem. 73: 2184-94 [PMID:10537079]

10. Bröer A, Wagner C, Lang F and Bröer S. (2000) Neutral amino acid transporter ASCT2 displays substrateinduced $\mathrm{Na}+$ exchange and a substrate-gated anion conductance. Biochem. J. 346 Pt 3: 705-10 [PMID:10698697]

11. Colleoni S, Jensen AA, Landucci E, Fumagalli E, Conti P, Pinto A, De Amici M, Pellegrini-Giampietro DE, De Micheli $C$ and Mennini T et al.. (2008) Neuroprotective effects of the novel glutamate transporter inhibitor (-)-3-hydroxy-4,5,6,6a-tetrahydro-3aH-pyrrolo[3,4-d]-isoxazole-4-carboxylic acid, which preferentially inhibits reverse transport (glutamate release) compared with glutamate reuptake. $J$. Pharmacol. Exp. Ther. 326: 646-56 [PMID:18451317]

12. Colton CK, Kong Q, Lai L, Zhu MX, Seyb KI, Cuny GD, Xian J, Glicksman MA and Lin CL. (2010) Identification of translational activators of glial glutamate transporter EAAT2 through cell-based highthroughput screening: an approach to prevent excitotoxicity. J Biomol Screen 15: 653-62 [PMID:20508255]

13. Coon and TR et al.. (2004) Abstract Viewer/ltinerary Planner, Program No. 168.10. Society for Neuroscience: 
14. Dunlop J. (2006) Glutamate-based therapeutic approaches: targeting the glutamate transport system.Curr Opin Pharmacol 6: 103-7 [PMID:16368269]

15. Dunlop J and Butera JA. (2006) Ligands targeting the excitatory amino acid transporters (EAATs).Curr Top Med Chem 6: 1897-906 [PMID:17017964]

16. Dunlop J, Eliasof S, Stack G, Mcllvain HB, Greenfield A, Kowal D, Petroski R and Carrick T. (2003) WAY855 (3-amino-tricyclo[2.2.1.02.6] heptane-1,3-dicarboxylic acid): a novel, EAAT2-preferring, nonsubstrate inhibitor of high-affinity glutamate uptake. Br. J. Pharmacol. 140: 839-46 [PMID:14517179]

17. Dunlop J, Mcllvain HB, Carrick TA, Jow B, Lu Q, Kowal D, Lin S, Greenfield A, Grosanu C and Fan Ket al.. (2005) Characterization of novel aryl-ether, biaryl, and fluorene aspartic acid and diaminopropionic acid analogs as potent inhibitors of the high-affinity glutamate transporter EAAT2. Mol. Pharmacol. 68: 974-82 [PMID:16014807]

18. Eliasof S, Mcllvain HB, Petroski RE, Foster AC and Dunlop J. (2001) Pharmacological characterization of threo-3-methylglutamic acid with excitatory amino acid transporters in native and recombinant systems. $J$. Neurochem. 77: 550-7 [PMID:11299317]

19. Esslinger CS, Agarwal S, Gerdes J, Wilson PA, Davis ES, Awes AN, O'Brien E, Mavencamp T, Koch HP and Poulsen DJ et al.. (2005) The substituted aspartate analogue L-beta-threo-benzyl-aspartate preferentially inhibits the neuronal excitatory amino acid transporter EAAT3. Neuropharmacology 49: 85061 [PMID:16183084]

20. Esslinger CS, Cybulski KA and Rhoderick JF. (2005) Ngamma-aryl glutamine analogues as probes of the ASCT2 neutral amino acid transporter binding site. Bioorg. Med. Chem. 13: 1111-8 [PMID:15670919]

21. Fontana AC, de Oliveira Beleboni R, Wojewodzic MW, Ferreira Dos Santos W, Coutinho-Netto J, Grutle NJ, Watts SD, Danbolt NC and Amara SG. (2007) Enhancing glutamate transport: mechanism of action of Parawixin1, a neuroprotective compound from Parawixia bistriata spider venom. Mol. Pharmacol. 72: 122837 [PMID:17646426]

22. Fontana AC, Guizzo R, de Oliveira Beleboni R, Meirelles E Silva AR, Coimbra NC, Amara SG, dos Santos WF and Coutinho-Netto J. (2003) Purification of a neuroprotective component of Parawixia bistriata spider venom that enhances glutamate uptake. Br. J. Pharmacol. 139: 1297-309 [PMID:12890709]

23. Gameiro A, Braams S, Rauen T and Grewer C. (2011) The discovery of slowness: low-capacity transport and slow anion channel gating by the glutamate transporter EAAT5. Biophys. J. 100: 2623-32 [PMID:21641307]

24. Ganel R, Ho T, Maragakis NJ, Jackson M, Steiner JP and Rothstein JD. (2006) Selective up-regulation of the glial $\mathrm{Na}+$-dependent glutamate transporter GLT1 by a neuroimmunophilin ligand results in neuroprotection. Neurobiol. Dis. 21: 556-67 [PMID:16274998]

25. Garaeva AA, Oostergetel GT, Gati C, Guskov A, Paulino C and Slotboom DJ. (2018) Cryo-EM structure of the human neutral amino acid transporter ASCT2. Nat. Struct. Mol. Biol. 25: 515-521 [PMID:29872227]

26. Gebhardt FM, Mitrovic AD, Gilbert DF, Vandenberg RJ, Lynch JW and Dodd PR. (2010) Exon-skipping splice variants of excitatory amino acid transporter-2 (EAAT2) form heteromeric complexes with full-length EAAT2. J. Biol. Chem. 285: 31313-24 [PMID:20688910]

27. Gendreau S, Voswinkel S, Torres-Salazar D, Lang N, Heidtmann H, Detro-Dassen S, Schmalzing G, Hidalgo $P$ and Fahlke C. (2004) A trimeric quaternary structure is conserved in bacterial and human glutamate transporters. J. Biol. Chem. 279: 39505-12 [PMID:15265858]

28. Goursaud S, Focant MC, Berger JV, Nizet Y, Maloteaux JM and Hermans E. (2011) The VPAC2 agonist peptide histidine isoleucine $(\mathrm{PHI})$ up-regulates glutamate transport in the corpus callosum of a rat model of amyotrophic lateral sclerosis ( $\mathrm{SSOD1G93A}$ ) by inhibiting caspase-3 mediated inactivation of GLT-1a. FASEB J. 25: 3674-86 [PMID:21730107]

29. Grewer C, Balani P, Weidenfeller C, Bartusel T, Tao Z and Rauen T. (2005) Individual subunits of the glutamate transporter EAAC1 homotrimer function independently of each other. Biochemistry 44: 11913-23 [PMID:16128593]

30. Grewer $C$ and Grabsch E. (2004) New inhibitors for the neutral amino acid transporter ASCT2 reveal its $\mathrm{Na+-dependent} \mathrm{anion} \mathrm{leak.} \mathrm{J.} \mathrm{Physiol.} \mathrm{(Lond.)} \mathrm{557:} \mathrm{747-59} \mathrm{[PMID:15107471]}$ 
31. Grewer C and Rauen T. (2005) Electrogenic glutamate transporters in the CNS: molecular mechanism, pre-steady-state kinetics, and their impact on synaptic signaling. J. Membr. Biol. 203: 1-20 [PMID:15834685]

32. Grunewald M and Kanner BI. (2000) The accessibility of a novel reentrant loop of the glutamate transporter GLT-1 is restricted by its substrate. J. Biol. Chem. 275: 9684-9 [PMID:10734120]

33. Huang S, Ryan RM and Vandenberg RJ. (2009) The role of cation binding in determining substrate selectivity of glutamate transporters. J. Biol. Chem. 284: 4510-5 [PMID:19074430]

34. Jensen AA, Erichsen MN, Nielsen CW, Stensbøl TB, Kehler J and Bunch L. (2009) Discovery of the first selective inhibitor of excitatory amino acid transporter subtype 1. J. Med. Chem. 52: 912-5 [PMID:19161278]

35. Jiang J and Amara SG. (2011) New views of glutamate transporter structure and function: advances and challenges. Neuropharmacology 60: 172-81 [PMID:20708631]

36. Kanai $Y$ and Hediger MA. (2003) The glutamate and neutral amino acid transporter family: physiological and pharmacological implications. Eur. J. Pharmacol. 479: 237-47 [PMID:14612154]

37. Kanai $Y$ and Hediger MA. (2004) The glutamate/neutral amino acid transporter family SLC1: molecular, physiological and pharmacological aspects. Pflugers Arch. 447: 469-79 [PMID:14530974]

38. Kim K, Lee SG, Kegelman TP, Su ZZ, Das SK, Dash R, Dasgupta S, Barral PM, Hedvat M and Diaz Pet al.. (2011) Role of excitatory amino acid transporter-2 (EAAT2) and glutamate in neurodegeneration: opportunities for developing novel therapeutics. J. Cell. Physiol. 226: 2484-93 [PMID:21792905]

39. Koch HP, Brown RL and Larsson HP. (2007) The glutamate-activated anion conductance in excitatory amino acid transporters is gated independently by the individual subunits. J. Neurosci. 27: 2943-7 [PMID:17360917]

40. Koch HP, Kavanaugh MP, Esslinger CS, Zerangue N, Humphrey JM, Amara SG, Chamberlin AR and Bridges RJ. (1999) Differentiation of substrate and nonsubstrate inhibitors of the high-affinity, sodiumdependent glutamate transporters. Mol. Pharmacol. 56: 1095-104 [PMID:10570036]

41. Lau CL, O'Shea RD, Broberg BV, Bischof L and Beart PM. (2011) The Rho kinase inhibitor Fasudil upregulates astrocytic glutamate transport subsequent to actin remodelling in murine cultured astrocytes. $\mathrm{Br}$. J. Pharmacol. 163: 533-45 [PMID:21309758]

42. Leary GP, Stone EF, Holley DC and Kavanaugh MP. (2007) The glutamate and chloride permeation pathways are colocalized in individual neuronal glutamate transporter subunits. J. Neurosci. 27: 2938-42 [PMID:17360916]

43. Lee A and Pow DV. (2010) Astrocytes: Glutamate transport and alternate splicing of transporters.Int. J. Biochem. Cell Biol. 42: 1901-6 [PMID:20883814]

44. Lee SG, Su ZZ, Emdad L, Gupta P, Sarkar D, Borjabad A, Volsky DJ and Fisher PB. (2008) Mechanism of ceftriaxone induction of excitatory amino acid transporter-2 expression and glutamate uptake in primary human astrocytes. J. Biol. Chem. 283: 13116-23 [PMID:18326497]

45. Levy LM, Warr O and Attwell D. (1998) Stoichiometry of the glial glutamate transporter GLT-1 expressed inducibly in a Chinese hamster ovary cell line selected for low endogenous $\mathrm{Na}+$-dependent glutamate uptake. J. Neurosci. 18: 9620-8 [PMID:9822723]

46. Machtens JP, Kovermann P and Fahlke C. (2011) Substrate-dependent gating of anion channels associated with excitatory amino acid transporter 4. J. Biol. Chem. 286: 23780-8 [PMID:21572047]

47. Nothmann D, Leinenweber A, Torres-Salazar D, Kovermann P, Hotzy J, Gameiro A, Grewer C and Fahlke C. (2011) Hetero-oligomerization of neuronal glutamate transporters. J. Biol. Chem. 286: 3935-43 [PMID:21127051]

48. Oppedisano F, Galluccio M and Indiveri C. (2010) Inactivation by Hg2+ and methylmercury of the glutamine/amino acid transporter (ASCT2) reconstituted in liposomes: Prediction of the involvement of a CXXC motif by homology modelling. Biochem. Pharmacol. 80: 1266-73 [PMID:20599776]

49. Palacín M, Estévez R, Bertran J and Zorzano A. (1998) Molecular biology of mammalian plasma membrane amino acid transporters. Physiol. Rev. 78: 969-1054 [PMID:9790568]

50. Pinilla-Tenas J, Barber A and Lostao MP. (2003) Transport of proline and hydroxyproline by the neutral 
amino-acid exchanger ASCT1. J. Membr. Biol. 195: 27-32 [PMID:14502423]

51. Reyes N, Ginter C and Boudker O. (2009) Transport mechanism of a bacterial homologue of glutamate transporters. Nature 462: 880-5 [PMID:19924125]

52. Romera C, Hurtado O, Mallolas J, Pereira MP, Morales JR, Romera A, Serena J, Vivancos J, Nombela F and Lorenzo $P$ et al.. (2007) Ischemic preconditioning reveals that GLT1/EAAT2 glutamate transporter is a novel PPARgamma target gene involved in neuroprotection. J. Cereb. Blood Flow Metab. 27: 1327-38 [PMID:17213861]

53. Rose EM, Koo JC, Antflick JE, Ahmed SM, Angers S and Hampson DR. (2009) Glutamate transporter coupling to Na,K-ATPase. J. Neurosci. 29: 8143-55 [PMID:19553454]

54. Rothstein JD, Patel S, Regan MR, Haenggeli C, Huang YH, Bergles DE, Jin L, Dykes Hoberg M, Vidensky $S$ and Chung DS et al.. (2005) Beta-lactam antibiotics offer neuroprotection by increasing glutamate transporter expression. Nature 433: 73-7 [PMID:15635412]

55. Ryan RM and Mindell JA. (2007) The uncoupled chloride conductance of a bacterial glutamate transporter homolog. Nat. Struct. Mol. Biol. 14: 365-71 [PMID:17435767]

56. Ryan RM, Mitrovic AD and Vandenberg RJ. (2004) The chloride permeation pathway of a glutamate transporter and its proximity to the glutamate translocation pathway. J. Biol. Chem. 279: 20742-51 [PMID:14982939]

57. Shigeri Y, Shimamoto K, Yasuda-Kamatani Y, Seal RP, Yumoto N, Nakajima T and Amara SG. (2001) Effects of threo-beta-hydroxyaspartate derivatives on excitatory amino acid transporters (EAAT4 and EAAT5). J. Neurochem. 79: 297-302 [PMID:11677257]

58. Shimamoto K, Lebrun B, Yasuda-Kamatani Y, Sakaitani M, Shigeri Y, Yumoto N and Nakajima T. (1998) DL-threo-beta-benzyloxyaspartate, a potent blocker of excitatory amino acid transporters. Mol. Pharmacol. 53: 195-201 [PMID:9463476]

59. Shimamoto K, Otsubo Y, Shigeri Y, Yasuda-Kamatani Y, Satoh M, Kaneko S and Nakagawa T. (2007) Characterization of the tritium-labeled analog of L-threo-beta-benzyloxyaspartate binding to glutamate transporters. Mol. Pharmacol. 71: 294-302 [PMID:17047096]

60. Shimamoto K, Shigeri Y, Yasuda-Kamatani Y, Lebrun B, Yumoto N and Nakajima T. (2000) Syntheses of optically pure beta-hydroxyaspartate derivatives as glutamate transporter blockers. Bioorg. Med. Chem. Lett. 10: 2407-10 [PMID:11078189]

61. Tamarappoo BK, McDonald KK and Kilberg MS. (1996) Expressed human hippocampal ASCT1 amino acid transporter exhibits a pH-dependent change in substrate specificity. Biochim. Biophys. Acta 1279: 131-6 [PMID:8603078]

62. Torres-Salazar D and Fahlke C. (2007) Neuronal glutamate transporters vary in substrate transport rate but not in unitary anion channel conductance. J. Biol. Chem. 282: 34719-26 [PMID:17908688]

63. Utsunomiya-Tate N, Endou $\mathrm{H}$ and Kanai Y. (1996) Cloning and functional characterization of a system ASC-like Na+-dependent neutral amino acid transporter. J. Biol. Chem. 271: 14883-90 [PMID:8662767]

64. Vandenberg RJ, Ju P, Aubrey KR, Ryan RM and Mitrovic AD. (2004) Allosteric modulation of neurotransmitter transporters at excitatory synapses. Eur J Pharm Sci 23: 1-11 [PMID:15324920]

65. Vandenberg RJ, Mitrovic AD, Chebib M, Balcar VJ and Johnston GA. (1997) Contrasting modes of action of methylglutamate derivatives on the excitatory amino acid transporters, EAAT1 and EAAT2. Mol. Pharmacol. 51: 809-15 [PMID:9145919]

66. Veruki ML, Mørkve SH and Hartveit E. (2006) Activation of a presynaptic glutamate transporter regulates synaptic transmission through electrical signaling. Nat. Neurosci. 9: 1388-96 [PMID:17041592]

67. Yernool D, Boudker O, Jin Y and Gouaux E. (2004) Structure of a glutamate transporter homologue from Pyrococcus horikoshii. Nature 431: 811-8 [PMID:15483603]

68. Zerangue $\mathrm{N}$ and Kavanaugh MP. (1996) ASCT-1 is a neutral amino acid exchanger with chloride channel activity. J. Biol. Chem. 271: 27991-4 [PMID:8910405]

69. Zerangue $\mathrm{N}$ and Kavanaugh MP. (1996) Flux coupling in a neuronal glutamate transporter.Nature 383: 634-7 [PMID:8857541]

70. Zerangue $\mathrm{N}$ and Kavanaugh MP. (1996) Interaction of L-cysteine with a human excitatory amino acid 
transporter. J. Physiol. (Lond.) 493 ( Pt 2): 419-23 [PMID:8782106]

71. Zhou LM, Gu ZQ, Costa AM, Yamada KA, Mansson PE, Giordano T, Skolnick P and Jones KA. (1997) (2S,4R)-4-methylglutamic acid (SYM 2081): a selective, high-affinity ligand for kainate receptors. J. Pharmacol. Exp. Ther. 280: 422-7 [PMID:8996224]

72. Zou S, Pita-Almenar JD and Eskin A. (2011) Regulation of glutamate transporter GLT-1 by MAGI-1 J. Neurochem. 117: 833-40 [PMID:21426345] 